\title{
Ruminal Nitrogen Metabolism: Perspectives for Integration of Microbiology and Nutrition for Dairy ${ }^{1,2}$
}

\author{
J. L. Firkins, ${ }^{3}$ Z. Yu, and M. Morrison ${ }^{4}$ \\ The MAPLE Research Initiative, Department of Animal Sciences, The Ohio State University, Columbus 43210
}

\begin{abstract}
Our objectives are to integrate current knowledge with a future perspective regarding how metagenomics can be used to integrate rumen microbiology and nutrition. Ruminal $\mathrm{NH}_{3}-\mathrm{N}$ concentration is a crude predictor of efficiency of dietary $\mathrm{N}$ conversion into microbial $\mathrm{N}$, but as this concentration decreases below approximately $5 \mathrm{mg} / \mathrm{dL}$ (the value most often suggested to be the requirement for optimal microbial protein synthesis), blood urea $\mathrm{N}$ transfer into the rumen provides an increasing buffer against excessively low $\mathrm{NH}_{3}-\mathrm{N}$ concentrations, and the supply of amino $\mathrm{N}$ might become increasingly important to improve microbial function in dairy diets. Defaunation typically decreases $\mathrm{NH}_{3}-\mathrm{N}$ concentration, which should increase the efficiency of blood urea $\mathrm{N}$ and protein-derived $\mathrm{NH}_{3}-\mathrm{N}$ conversion into microbial protein in the rumen. Thus, we explain why more emphasis should be given toward characterization of protozoal interactions with proteolytic and deaminating bacterial populations. In contrast with research evaluating effects of protozoa on $\mathrm{N}$ metabolism, which has primarily been done with sheep and cattle with low dry matter intake, dairy cattle have greater intakes of readily available carbohydrate combined with increased ruminal passage rates. We argue that these conditions decrease protozoal biomass relative to bacterial biomass and increase the efficiency of protozoal growth, thus reduc-
\end{abstract}

Received August 8, 2006.

Accepted October 17, 2006.

${ }^{1}$ Presented at the ADSA-ASAS Joint Annual Meeting, Minneapolis, MN, July 2006.

${ }^{2}$ Research was supported by state and federal funds appropriated to the Ohio Agricultural and Development Center (OARDC), The Ohio State University. Manuscript number 28-06AS. Research findings included in this manuscript were supported by OARDC (OHOG0592500486 and OHOA1075-55019, to M.M. and Z.Y.) as well as National Research Initiative Competitive Grant nos. 970-3653, 2002-03630, and 2003-35206-12872 from the USDA Cooperative State Research, Education, and Extension Service.

${ }^{3}$ Corresponding author: firkins.1@osu.edu

${ }^{4}$ Current address: CSIRO Livestock Industries, Queensland Biosciences Precinct, University of Queensland, 306 Carmody Road, St Lucia, Queensland, Australia 4067. ing the negative effects of bacterial predation compared with the beneficial effects that protozoa have on stabilizing the entire microbial ecosystem. A better understanding of mechanistic processes altering the production and uptake of amino $\mathrm{N}$ will help us to improve the overall conversion of dietary $\mathrm{N}$ into microbial protein and provide key information needed to further improve mechanistic models describing rumen function and evaluating dietary conditions that influence the efficiency of conversion of dietary $\mathrm{N}$ into milk protein.

Key words: bacterial metagenomics, microbial protein synthesis, protozoa, rumen microbial ecology

\section{INTRODUCTION}

Considerable progress has been made in dairy nutrition as we have shifted from a CP-based requirements system to a metabolizable protein system (NRC, 2001). Firkins et al. (2006) highlighted the importance of predicting microbial $\mathrm{N}$ flow to the duodenum more accurately and precisely for improved effectiveness of this metabolizable protein system. Users should be aware that a small but repeatable error in the NRC (2001) equation for passage rate (kp) has recently surfaced (Seo et al., 2006); however, these authors supported the general robustness of the equations, noting that more progress is needed to improve predictions of $\mathrm{kp}$ under more varied conditions. Moreover, Huhtanen (2005) emphasized that, when compared against milk protein (which does not have flow marker errors and can be quantified more reliably than metabolizable protein), the amount of microbial protein synthesis (MPS; i.e., in this case, the amount of microbial protein reaching the duodenum) seldom seemed limited by RDP supply in many previous studies. Such a conclusion contrasts with conclusions from older research that many studies probably limited MPS when they substituted protein sources high in RDP for those high in RUP (Stern et al., 1994). Some of the discrepancy in these reports could be a result of collectively lumping all aspects of $\mathrm{kp}$, protein degradability, and MPS into an overall dietary treatment effect without regard 
to how ruminal microbial populations can interact with those dietary conditions.

Several systems have been derived to model the transfer rates among various ruminal N pools (Dijkstra et al., 1998a), yet relatively few have actually quantified the flux of amino- $\mathrm{N}$ and $\mathrm{NH}_{3}-\mathrm{N}$ in the rumen of dairy cattle. Consequently, we are left trying to relate concentrations of $\mathrm{N}$-containing fractions in ruminal fluid to duodenal or omasal flows of microbial N. Theoretically, when nitrogen pools approach their optima with respect to MPS, then the residual pool sizes should be decreasing. In this case, a low concentration of a nitrogenous compound such as $\mathrm{NH}_{3}$ could thereby show a highly efficient usage rate, whereas another situation with a similar concentration could indicate deficient concentrations for MPS. More direct and quantitative measurements of microbial protein synthesis are required, particularly for the separation of fluxes (not concentration) of the nitrogenous precursors into microbial protein and further separating MPS into its components: actual production and recycling. For the latter, recycling could further be distinguished as recycling through the microbial nonammonia $\mathrm{N}$ and the ruminal $\mathrm{NH}_{3}-\mathrm{N}$ pools (Oldick et al., 2000). Microbial nonammonia $\mathrm{N}$ recycling should be a result of a low efficiency of MPS (EMPS; the amount of net MPS per unit of available energy), whereas increased recycling through the $\mathrm{NH}_{3}-\mathrm{N}$ pool probably enhances inefficient whole-body $\mathrm{N}$ usage. One aim of the current review is to integrate some current data for $\mathrm{N}$ fluxes with our perspective toward prioritizing future research objectives to improve the efficiency of $\mathrm{N}$ usage in dairy cattle.

Recent reviews on ruminal $\mathrm{N}$ metabolism are available, including recent book chapters with both nutrition and microbiology perspectives (Hristov and Jouany, 2005; Walker et al., 2005; Firkins and Yu, 2006). Recent advances in molecular biology and genomics now offer new opportunities to conduct a more holistic examination of the structure and function of rumen microbial communities, including those organisms that cannot readily be cultured. This meta-analysis of the genetic potential resident in microbial communities is often referred to as metagenomics and, in general terms, is enabled by several advances in the life sciences. These include the construction of metagenomic libraries containing relatively large fragments ( $>40$ to $150 \mathrm{~kb}$ ) that can be archived and examined to better understand the microbial biology underpinning rumen function as well as gene discovery for biotechnological applications (Schloss and Handelsman, 2003; Galperin, 2004). Second, the methodologies used for high throughput DNA sequencing are becoming increasingly time- and cost-efficient, and the sequencing and bioinformatics analysis of large DNA fragments retrieved directly from microbiomes is now a viable and attractive way to increase understanding of microbial processes. Third, the ever-expanding databases of semantides (i.e., large information-bearing molecules such as the gene encoding small subunit ribosomal RNA) not only serve as measures of biodiversity but also lead to quantitative (real-time) PCR methods of assessing microbial diversity and population dynamics (Larue et al., 2005). For instance, clones from metagenomic libraries carrying this or other highly conserved genes provide a phylogenetic link to previously characterized species and allow assignment of previously unrecognized genetic potential to a specific phylogenetic group. For these reasons, metagenomics expands our scientific capabilities and understanding beyond the small percentage of ruminal microbes that can currently be cultivated in the laboratory, permitting a more holistic and mechanistic analysis of microbial communities. In that context, we narrowed our focus in this review toward justifying the need for further in vivo analyses of microbial populations, particularly with regard to emerging (meta)genomics approaches for a more complete and accurate evaluation of bacterial populations and to reconsideration for the role of protozoa in the rumen of lactating dairy cattle. Whenever possible, we will try to provide a transition from previous to prospective concepts to help prioritize future opportunities for collaborative microbiological and nutritional research on ruminal $\mathrm{N}$ metabolism.

\section{QUANTIFYING MICROBIAL N METABOLISM IN DAIRY CATTLE}

\section{Ammonia $\mathrm{N}$ as an Indicator for Availability of $N$ Precursors for MPS}

Ruminal $\mathrm{NH}_{3}-\mathrm{N}$ is typically measured in most nutrition studies but often can vary from study to study, the significance of which needs further research attention. In the study of Klusmeyer et al. (1990), the mean concentration of ruminal $\mathrm{NH}_{3}-\mathrm{N}$ was 10.5 and $5.4 \mathrm{mg} /$ $\mathrm{dL}$ for dairy cows fed $14.5 \% \mathrm{CP}$ diets containing soybean meal or corn gluten meal, respectively. These diets, particularly those with corn gluten meal, would likely be deficient in RDP (cows' DMI were about 3.7\% of BW). Yet, decreasing CP further to $11.0 \%$, which would almost surely force $\mathrm{CP}$ to be more limiting than $\mathrm{NE}_{\mathrm{L}}$, only decreased the mean $\mathrm{NH}_{3}-\mathrm{N}$ to 2.5 and 1.9 $\mathrm{mg} / \mathrm{dL}$, respectively. Two recent studies with cannulated dairy cattle with high DMI averaged about 7.2 $\mathrm{mg} / \mathrm{dL}$ (Oba and Allen, 2003) compared with $19.5 \mathrm{mg} /$ $\mathrm{dL}$ (Voelker and Allen, 2003) for $\mathrm{NH}_{3}-\mathrm{N}$, even though the diets were similar (approximately 18\% CP). When grain concentration was increased (forage NDF was 
Table 1. Effects of purified carbohydrate sources on ruminal ammonia $\mathrm{N}$ usage in dairy cattle ${ }^{1}$

\begin{tabular}{lccc}
\hline Item & Glucose & Starch & Fiber \\
\hline $\mathrm{NH}_{3}-\mathrm{N}, \mathrm{mg} / \mathrm{dL}$ & $8.5^{\mathrm{a}}$ & $9.6^{\mathrm{a}}$ & $16.4^{\mathrm{b}}$ \\
$\mathrm{NH}_{3}-\mathrm{N}$ production, g/d & $350^{\mathrm{b}}$ & $487^{\mathrm{a}}$ & $533^{\mathrm{a}}$ \\
$\mathrm{NH}_{3}-\mathrm{N}$ ILR, g/d & $230^{\mathrm{b}}$ & $343^{\mathrm{a}}$ & $320^{\mathrm{a}}$ \\
Microbial N flow, g/d & $197^{\mathrm{a}}$ & $185^{\mathrm{a}}$ & $153^{\mathrm{b}}$ \\
Microbial N derived from $\mathrm{NH}_{3}-\mathrm{N}$, g/d & $75^{\mathrm{b}}$ & $111^{\mathrm{a}}$ & $74^{\mathrm{b}}$ \\
Bacterial N derived from $\mathrm{NH}_{3}-\mathrm{N}, \%$ & $33^{\mathrm{a}}$ & $33^{\mathrm{a}}$ & $23^{\mathrm{b}}$ \\
Protozoa, log 10 /mL & 5.26 & 5.21 & 5.42 \\
Butyrate, mol/100 mol & 18.2 & 10.8 & 9.1 \\
pH & $6.00^{\mathrm{a}}$ & $6.19^{\mathrm{b}}$ & $6.41^{\mathrm{c}}$ \\
\hline
\end{tabular}

${ }^{\mathrm{a}-\mathrm{c}}$ Means within a row with different superscripts differ $(P<0.05)$.

${ }^{1} 20.6 \%$ of the diet was glucose, cornstarch, oat fiber, or a combination that is not shown in the current table. Data are from Hristov et al. (2005). Butyrate data were converted to a molar percentage here to standardize for differences in total VFA concentration, so statistics were not done.

${ }^{2} \mathrm{ILR}=$ irreversible loss rate.

decreased from 25.4 to $16.5 \%$ ), ruminal $\mathrm{NH}_{3}-\mathrm{N}$ concentration decreased but still averaged above $5.1 \mathrm{mg} / \mathrm{dL}$ (Oba and Allen, 2003). Despite these differences, the minimum $\mathrm{NH}_{3}-\mathrm{N}$ concentration measured was 1.4 to $1.6 \mathrm{mg} / \mathrm{dL}$, which is below the mean for cows fed $11.0 \%$ CP in Klusmeyer et al. (1990). The studies outlined above seem to support the importance of BUN being transferred back into the rumen, which seems to buffer the rumen from low ruminal $\mathrm{NH}_{3}-\mathrm{N}$ concentration. In addition, greater cycling of BUN to the rumen probably increases the likelihood that amino-N precursors might become more limiting for MPS than $\mathrm{NH}_{3}-\mathrm{N}$ in dairy cattle fed high amounts of rumen-degraded starch. There is considerable BUN cycling that influences the efficiency of dietary $\mathrm{N}$ conversion into milk protein (Firkins and Reynolds, 2005; Hristov and Jouany, 2005), and clearly more work is needed to incorporate variable BUN cycling with the need for amino-N vs. $\mathrm{NH}_{3}-\mathrm{N}$ for ruminal microbes.

Carbohydrate supply profoundly influences the amount of ruminal $\mathrm{NH}_{3}-\mathrm{N}$ assimilated into microbial protein. Hristov et al. (2005) fed diets high in alfalfa hay that were supplemented with $20.6 \%$ purified glucose, starch, or oat fiber. The diets contained approximately $18 \%$ CP. As seen in Table 1, feeding glucose decreased ammonia production (which includes BUN transfer into the ammonia $\mathrm{N}$ pool) and irreversible loss (which includes ammonia absorption plus ammonia converted into microbial protein). This decreased the amount of microbial $\mathrm{N}$ synthesized from ammonia on a gram/day basis but not on a percentage basis when compared with starch. Although ammonia N production and irreversible loss were comparable for fiber compared with starch, the amount of microbial $\mathrm{N}$ flow was lower, apparently because of lower energy to support MPS. Thus, less ammonia $\mathrm{N}$ was converted into microbial $\mathrm{N}$ for the fiber treatment even though one might expect the fiber to stimulate the abundance of ammonia-using cellulolytic bacteria. Because protozoal counts were not influenced, the greater $(P<0.05)$ butyrate concentration on the glucose diet could be a result of changes in bacterial populations. Emerging quantitative methods integrated with metagenomics analyses would help to determine if butyrate-producing bacteria such as Butyrivibrio or Megasphaera spp. (Marounek et al., 1989; Brown et al., 2006) could be altering proteolysis and deamination rates, which, along with the lower $\mathrm{pH}$, could be depressing the hyperammonia-producing bacterial populations. As such, a population shift could moderate ruminal proteolysis and (or) deamination. Current data now support that AA stimulate fibrolytic bacteria (Bach et al., 2004; Walker et al., 2005), perhaps especially those involved in the degradation of hemicelluloses (Griswold et al., 2003). Consequently, would a decrease in deamination without a decrease in proteolysis improve fiber digestibility? Decreasing the forage:grain ratio might not reduce measured ruminal fiber digestibility, but it might have increased the potentially available fiber in the diet (i.e., similar fiber digestibility relative to an increase in potential digestibility represents an opportunity loss). For these reasons, a more holistic examination of the biofilms adherent to plant biomass in the rumen might provide further functionally relevant insights into ruminal $\mathrm{N}$ transactions as well as fiber degradation.

Carbohydrate source and availability appear to influence the amount of MPS and EMPS in potentially different ways. Increasing the percentage grain in a ration increased microbial $\mathrm{N}$ flow to the duodenum by about 30\% (Oba and Allen, 2003), but EMPS was not affected by level of grain; instead, EMPS was increased when high-moisture corn was replaced with dry ground corn (no interaction when corn source was factorialized with grain level). High-moisture corn might stimulate rumination (Firkins et al., 2001), which could prevent decreased $\mathrm{pH}$ and reflect increased retention time, which would support greater starch digestibility (Oba and Allen, 2003). The lower EMPS could therefore be a result of much higher energy availability relative to other factors, such as peptide supply, to support MPS. In another study (Voelker and Allen, 2003) in which high-moisture corn was reduced from 36 to $11 \%$ of DM by substitution with beet pulp, microbial $\mathrm{N}$ flow was linearly decreased without affecting EMPS. In this case, the amount of rumen-degradable starch was probably decreased below the levels needed to support optimum MPS. Collectively, if RDP is deemed sufficient based merely on ruminal $\mathrm{NH}_{3}-\mathrm{N}$ concentrations from those studies (ignoring amino-N 
availability), there seems to be an optimum range of rumen-degraded starch above which MPS might be attenuated or even decreased because of energy spilling reactions and below which MPS will be reduced because of limiting substrate availability. Only through more elaborate study of types of microbes involved in these diets can we better predict how energy spilling influences EMPS because many bacteria cope in different ways (Russell, 1998). Yet, we need to consider the entire microbial community, not just a combination of individual groups or species, because the community structure dictates the overall metabolism of the entire ecosystem. Moreover, compared with the dozens of studies evaluating ruminal $\mathrm{NH}_{3}-\mathrm{N}$ requirements for MPS (Hoover, 1986), there have been few studies actually quantifying nonammonia RDP usage in dairy situations, probably because of a limitation in systematic, robust methodology for measurement of peptides.

The notion that the lower value of energy-available MPS or RDP-available MPS should be used in many supply models ignores how microbial populations change with varying RDP (or, more accurately, peptide) supply or how these populations can change their metabolism under different conditions. For example, the Cornell Net Carbohydrate and Protein System (Fox et al., 2004), which estimates peptide supply and requirements for bacteria degrading nonstructural carbohydrates, seemed to predict the MPS well despite underpredicting EMPS in a recent evaluation (Offner and Sauvant, 2004). According to that evaluation, it seemed to underpredict ruminal NDF digestibility but overpredict starch digestibility. Given the distinctions of how different microbial populations are affected by different dietary conditions and how this can influence predictions, we consider it very important to integrate microbial ecology and function with output of microbial products under different dietary conditions so that these different conditions can be predicted more robustly and predictably.

Many components of rumen models are based on equations that were derived, or for which the feed library is calibrated, using in vitro conditions that might not apply in vivo (Dijkstra et al., 2005). For example, these authors elaborated on the large importance of substrate availability on bacterial growth in batch culture that is not necessarily reflective of semicontinuous input of substrate and the ramifications of passage that are more important in vivo. The in vivo degradation rate might be positively related to the in vivo $\mathrm{kp}$, $\mathrm{pH}$ is regulated differently, and protozoal metabolism might be compromised in vitro, thus complicating the prediction of MPS and EMPS based on in vitro-derived parameterization of models. Therefore, we find an ex- panding need to couple meta-analyses of microbial communities and their functionality (e.g., enzymatic activity) using in vivo nutrition experiments.

\section{Considerations for Efficiency of MPS}

Continuous culture experiments have advanced our mechanistic understanding of bacterial ecology; however, not all conditions can be directly extrapolated to in vivo situations. Although the original chemostat work of Isaacson et al. (1975) documented the effects of kp on EMPS, the changes in kp were also concurrent with changes in substrate availability (input of substrate increased with increasing $\mathrm{kp}$ ). Consequently, the Cornell Net Carbohydrate and Protein System based predictions for MPS and EMPS on rate of carbohydrate degradation (Russell et al., 1992), whereas others have argued that the effect of $\mathrm{kp}$ should have an important function independent from substrate supply (Dijkstra et al., 1998a, 2005). With increasing infusion rate of substrate, theoretically more energy can be spent on growth functions and less on maintenance. However, greater infusion rate can also increase the number of bacteria or change the substrate concentration inside the fermenters, which can affect bacterial populations that vary in affinity toward that substrate (Firkins and $\mathrm{Yu}, 2006$ ). A dual-flow continuous culture system more accurately allows the effects of $\mathrm{kp}$ to be separated from changes in substrate availability. There have been relatively few studies measuring EMPS in these systems with increasing $\mathrm{kp}$ (Bach et al., 2004). As these authors explained, the benefit of increasing $\mathrm{kp}$ on EMPS can be overcome by decreased washout of substrate. In another study, Qiu et al. (2004) increased the solids dilution rate from 4 to $8 \%$ / $\mathrm{h}$. Interestingly, increasing kp decreased $(P<0.05)$ the most-probable number of total bacteria and cellulolytics (from $10^{9.85}$ to $10^{9.22}$ and from $10^{8.53}$ to $10^{8.09}$ cells/ $\mathrm{mL}$, respectively) in the fermenters. Yet, despite only a $15 \%$ decrease in the true OM digestibility, the EMPS increased from 31.4 to $43.6 \mathrm{~g}$ of N/kg of OM truly digested (a 39\% improvement). Although not significant because of a high SE ( $4.7 \mathrm{~g}$ of N/kg of OM truly digested), a simple $t$ statistic would document this difference to be approximately $P \leq 0.12$. We suggest that the reason for the increased EMPS is not actually explained by the lower OM digestibility, which is the explanation sometimes given, or even a general explanation that increasing $\mathrm{kp}$ dilutes the nongrowth energy usage by bacteria (Dijkstra et al., 2005). Rather, we suggest that increasing EMPS with increasing kp should somehow be moderated through changing the expression of genes in bacteria that help maintain cell numbers and activity compared with competing popu- 
lations. For example, if increasing kp corresponds with increasing substrate supply (i.e., greater DMI), then there could be a greater proportion of cells in logarithmic growth than in other growth phases; the abundance of mRNA for growth-related enzymes as a proportion of total mRNA should be greater than with lower substrate supply. If increasing $\mathrm{kp}$ was not accompanied with greater substrate supply, then there could be greater selection pressure toward strategist populations; for example, microbes with a high affinity for substrate or possessing other strategies for heightened competition when substrate is diminishing. Finally, if increasing kp were further increased concomitantly with decreased substrate concentration (faster passage than input of substrate), then bacteria could induce substrate-scavenging systems that increase their maintenance energy needs (Notley and Ferenci, 1996), which should lower EMPS. Emerging functional genomics approaches should help explain these mechanisms in the complex ruminal ecosystem. With better understanding of the mechanism, we might be better able to explain interactions among dietary conditions.

Despite its inherent importance in models of in vivo metabolism, there are few in vivo data relating $\mathrm{kp}$ to microbial growth in vivo. Firkins et al. (1987) reported that increasing feed intake increased the counts of bacteria relative to counts of protozoa; however, because the protozoal counts were not correlated with EMPS, they questioned if the strong correlation of increasing EMPS with increasing kp was a result of decreased protozoal predation of bacteria, suggesting instead that increasing $\mathrm{kp}$ directly influenced bacterial growth.

Researchers seem to be increasingly using a single compartment model (often termed the "pool and flux model") in which input of nutrients must equal the flux of those nutrients through the rumen (Firkins et al., 1998). The flux equals the pool size in the rumen multiplied by the turnover rate (usually degradation rate $+\mathrm{kp}$ ). We caution that the $\mathrm{kp}$ of indigestible NDF need not be the same as that of potentially digestible NDF (Harvatine et al., 2002). However, even if duodenal flow is calculated directly (so the $\mathrm{kp}$ of indigestible and digestible NDF can be determined separately), we note a continuing trend to use individual-cow calculations, and we contend that such measurements could magnify error in duodenal flow markers when used in regression. To support this contention, we simulated an experiment in which a cow has a DMI of $20.0 \mathrm{~kg} /$ $\mathrm{d}$. By taking typical values for OM, N, and RNA concentrations in feed, duodenal digesta, and a bacterial reference from several studies from our laboratory, we performed a sensitivity analysis of the duodenal $\mathrm{Cr}_{2} \mathrm{O}_{3}$
Table 2. Simulation of error from a duodenal flow marker $\left(\mathrm{Cr}_{2} \mathrm{O}_{3}\right)$ and resulting collinearity from different within-cow calculations ${ }^{1}$

\begin{tabular}{lcrc}
\hline & $\mathrm{Cr}_{2} \mathrm{O}_{3}, \%$ of its true value \\
\cline { 2 - 4 } Item & 90 & 100 & 110 \\
\hline OM intake, kg/d & 18.6 & 18.6 & 18.6 \\
True ${ }^{2} \mathrm{OM}$ flow, kg/d & 10.2 & 9.2 & 8.3 \\
True OM digested in the stomach, kg/d & 8.4 & 9.4 & 10.3 \\
\% of OM intake & 45.2 & 50.7 & 55.2 \\
Bacterial N & 304 & 273 & 248 \\
g/d & 36.1 & 29.0 & 24.2 \\
g/kg of OM truly digested & 0.052 & 0.047 & 0.043 \\
Passage rate of indigestible $\mathrm{OM}^{3} / \mathrm{h}$ & & &
\end{tabular}

${ }^{1}$ Simulation with $20 \mathrm{~kg} / \mathrm{d}$ of DMI and use of a single duodenal flow marker $\left(\mathrm{Cr}_{2} \mathrm{O}_{3}\right)$ the deviation of which from its expected true value (100\%) from sampling or laboratory errors is the sole change in the calculations.

${ }^{2}$ True $\mathrm{OM}=$ total $\mathrm{OM}$ - bacterial OM.

${ }^{3}$ Duodenal flow of indigestible OM (g/d)/ruminal pool size $(\mathrm{g})$ of indigestible OM using the pool and flux method (Firkins et al., 1998).

concentration (Table 2). In this example, underestimating the $\mathrm{Cr}_{2} \mathrm{O}_{3}$ concentration by $10 \%$ increased the calculation for duodenal flow obviously by $10 \%$. Consequently, it decreased OM truly digested while simultaneously increasing MPS. The result is a compounded $24 \%$ increase in EMPS. In another simulation, the reverse happened (17\% decrease in EMPS) when the $\mathrm{Cr}_{2} \mathrm{O}_{3}$ recovery was changed to $110 \%$. Thus, if one cow had a $10 \%$ underestimation of $\mathrm{Cr}_{2} \mathrm{O}_{3}$ concentration and another had a $10 \%$ overestimation, the mean $(100 \%)$ would be only moderately biased (mean of $24 \%$ and $-17 \%=3.5 \%$ overestimation). With randomization of experimental units across treatments, the difference among means should be relatively accurate. However, if these 2 hypothetical individual values were used in a regression using numerous variables, there could be a profound latent response (Firkins et al., 2006) in which the $24 \%$ overestimation and the $17 \%$ underestimation would both directly influence the regression, particularly if they become extreme data that can have more leverage. For example, regressing 36.1 vs. 8.4 and 24.2 vs. 10.3 for EMPS and OM truly digested for the 90 and $110 \%$ recoveries shown in Table 2 would force an inverse relationship when these points were really just deviations resulting from normal error that is not random. In contrast, the correlation of EMPS with $\mathrm{kp}$ that was measured using the dilution of $\mathrm{Yb}$ that was sprayed onto feed (Firkins et al., 1987) should have a minimal latent response because independent markers were used, whereas the accuracy of the regression could be suspect because of $\mathrm{Yb}$ migration (Firkins et al., 1998). Researchers seem to pay equal attention to experimental error from methods and from statistics with calculations that become part of regressions rather than focusing only on the algebraic 
regression formula and $\mathrm{r}^{2}$ if they wish to discern the true biological relationships among in vivo-derived data.

Comparing means (which should have minimal bias) from the pool and flux method, Harvatine and Allen (2006) reported that increasing the unsaturation of supplemental fat did not increase the ruminal pool of linoleic acid and only marginally $(P=0.15)$ increased the pool of 18:1 cis fatty acids. Interestingly, increasing the unsaturation of fat linearly decreased the ruminal $\mathrm{kp}$ of total 18-carbon fatty acids and affected the rates of biohydrogenation of certain fatty acids, showing how the animal's physiology can interact with microbial ecology. In another study (Lewis et al., 1999), when the particle size of forage was reduced, the antimicrobial effects of unsaturated fat were decreased, perhaps through increasing $\mathrm{kp}$ of fat adsorbed to forage particles. Bateman and Jenkins (1998) further documented that feeding increasing levels of unsaturated fat resulted in a nonlinear rise to a plateau of ruminal concentration of free fatty acids. Because biohydrogenation removes the inhibition of unsaturated fatty acids on protozoa and other microbes, these studies clearly illustrate the challenges with isolating separate effects of source and amount of dietary fat on factors affecting the efficiency of conversion of dietary $\mathrm{N}$ into microbial $\mathrm{N}$. These nonadditive responses justify mechanistic examination of microbial community structure and function under these different dietary circumstances. If inhibitory concentrations of specific fatty acids can be determined, then kinetic models of biohydrogenation (Harvatine and Allen, 2006) could be used to better predict effects of fat on ruminal microbial populations, and as part of studies like those cited herein, samples can be collected and stored for subsequent potential protozoal counting or prokaryote community analyses.

\section{THE IMPORTANCE OF PROTOZOA TO RUMINAL N METABOLISM}

\section{Reconsidering the Role of Protozoa on Whole Body N Metabolism}

Rumen protozoa have long been thought to be a very important contributor to inefficient ruminal N metabolism (Firkins, 1996). In past decades, much information on protozoa was gleaned from faunated periods vs. defaunated periods with the same animals (Hristov and Jouany, 2005). The by-difference calculation of faunated (or refaunated) minus the defaunated period data represents protozoal contribution to fiber digestibility or their effects on $\mathrm{N}$ recycling and assumes that the intentional confounding of treatment with period is not a problem. However, such assumptions might not be biologically appropriate. For example, synergism between protozoa and live (but not killed) bacteria on starch degradation was documented (Fondevila and Dehority, 2001), and protozoa help scavenge oxygen, which benefits bacteria with less aerotolerance (Dehority, 2003). Dijkstra and Tamminga (1995) modeled protozoal contribution to microbial biomass, predicting NDF degradation in the rumen to be a function of RDP supply. However, protozoal fibrolytic activity appears to be less than that of bacteria (Firkins and $\mathrm{Yu}, 2006)$, so a decrease in ruminal fiber digestibility by defaunation seems unlikely to be a result of loss of fibrolytic activity per se. Hristov and Jouany (2005) further outlined several benefits of protozoa on the overall microbial community and potential concerns regarding residual effects of defaunating agents. In their summary of faunated-defaunated comparisons, urinary $\mathrm{N}$ excretion was only decreased, on average, by $8 \%$ by defaunation. However, it might be inappropriate for these studies with low-producing animals for which $\mathrm{CP}$ was very unlikely to limit whole-body $\mathrm{N}$ retention to be extended to make conclusions for animals exhibiting rapid growth or high milk production. For example, in the in vivo studies reporting ${ }^{15} \mathrm{~N}$ kinetics (Hristov and Jouany, 2005), the authors would have needed to make RDP very close to requirements to improve whole-body $\mathrm{N}$ efficiency; however, if $\mathrm{CP}$ and RDP were limited by study design, then the researchers would have risked suppression of OM digestibility from reduced $\mathrm{NH}_{3}-\mathrm{N}$ concentration per se (defaunation typically decreases it; Hristov and Jouany, 2005). Yet, hypotheses based on metagenomics approaches could still be tested if defaunation decreases $\mathrm{NH}_{3}-\mathrm{N}$ concentration below a threshold that influences $\mathrm{N}$ metabolism separately from studying how protozoa affect bacterial predation.

In a study with yearling sheep fed $15.5 \% \mathrm{CP}$ diets (Koenig et al., 2000), $\mathrm{N}$ retention was not improved by defaunation (it actually decreased), although these conditions (high $\mathrm{CP}$ and low ADG) would not be expected to yield much change. The fractional turnover rate of bacterial $\mathrm{N}$ was decreased. However, the recycling of microbial $\mathrm{N}$ through the $\mathrm{NH}_{3}-\mathrm{N}$ pool was not affected. We note a pattern in decreased $\mathrm{NH}_{3}-\mathrm{N}$ pool size and decreased amount of $\mathrm{NH}_{3}-\mathrm{N}$ that was recycled via plasma urea $\mathrm{N}$ combined with a greater flow of microbial $\mathrm{N}$ derived from $\mathrm{NH}_{3}-\mathrm{N}$; this pattern supports previous discussion that perhaps the greatest opportunity of whole body $\mathrm{N}$ retention is through reducing ruminal $\mathrm{NH}_{3}-\mathrm{N}$ pool size consistently without limiting $\mathrm{NH}_{3}-\mathrm{N}$ for important bacterial functions. In a study with lactating dairy cattle fed sodium laurate to depress protozoal numbers to less than $10 \%$ of control (Hristov et al., 2004), urinary $\mathrm{N}$ was not decreased by 
the treatment. The diets contained $19.7 \% \mathrm{CP}$, which again likely exceeded requirements for milk production and would not be expected to yield much of a change in $\mathrm{N}$ retention. The irreversible loss rate of ruminal $\mathrm{NH}_{3}-\mathrm{N}$ was numerically decreased by $16 \%$ even though $\mathrm{NH}_{3}-\mathrm{N}$ pool size was numerically increased by $24 \%$ with the laurate treatment. Neither trend approached significance, but opposing trends could be interpreted to support the need to measure flux rates, not just concentrations. Concentrationdependent diffusion of $\mathrm{NH}_{3}-\mathrm{N}$ from the rumen into the blood and diffusion of urea from blood back into the rumen should both decrease by suppression of protozoal biomass in the rumen if that decreases $\mathrm{NH}_{3}-\mathrm{N}$ concentration. Consequently, if the benefit of reducing $\mathrm{NH}_{3}-\mathrm{N}$ recycling from reduced protozoal activity can be balanced with the stabilization effect of protozoa on the entire ruminal ecosystem, we should be able to eventually improve efficiency of $\mathrm{N}$ metabolism in diets in which RDP supply is more closely balanced with requirements. This means that the optimum protozoal population size could vary with diet and perhaps with distribution of protozoal genera. To reliably improve efficiency of $\mathrm{N}$ metabolism in the rumen through protozoa suppression, though, more attention must be given to the considerable difference in protozoal populations among animals (Regensbogenova et al., 2004; Sylvester et al., 2005). Finally, to adapt protozoal ecology to a nutrition perspective, better quantification of protozoal biomass in the rumen and resulting outflow to the duodenum must be combined with more fundamental knowledge of protozoal function, growth, and effects on $\mathrm{N}$ metabolism. Therefore, these aspects will be discussed in subsequent sections.

\section{Protozoa and MPS}

In a review of various dietary and ruminal factors influencing $\mathrm{N}$ metabolism, Hristov and Jouany (2005) cited a statistical compilation describing how defaunation in sheep influenced MPS and EMPS. We simulated the data, confirmed the original regression, and then fit different statistical models to their data (Figure 1). The EMPS tends to be constantly improved by about $20 \%$ by defaunation (panel A), but their reported regression (slope is $<1$ ) does not support an overall improvement in the amount of MPS (panel B). Our alternative regressions support a modest overall net benefit for defaunation for all but the latter 2 points (panel C) or the benefit of defaunation decreases and later becomes detrimental with increasing MPS (panel D). These large differences in interpretation between the latter 3 panels clearly highlight the need for more in vivo experiments done at high levels of DMI and with high amounts of MPS for more accurate extrapolation to production situations, particularly for dairy cattle for which the amount of MPS should be maximized for efficient use of dietary CP. Even assuming panel $\mathrm{C}$ to be correct, only a $7 \%$ average improvement in MPS for defaunation supports our view that too much attention has been paid to the effect of protozoal predation of bacteria as the major factor influencing the economy of $\mathrm{N}$ usage in the rumen and not enough attention has been paid to its effect on total microbial ecology. For example, in various marine and soil ecosystems, much more information seems to be known regarding how the bacterial populations respond to protozoal predation (e.g., see Matz and Kjelleberg, 2005). Only recently have investigators evaluated how protozoa influence bacterial populations in the rumen (Ozutsumi et al., 2005, 2006), and the functional significance of these changes is not yet known. Because so many of the rumen bacterial rRNA gene sequences recovered from clone libraries are related to uncharacterized bacteria (Edwards et al., 2004; Firkins and $\mathrm{Yu}, 2006$ ), we surmise that metagenomic approaches based on emerging technology with greatly expanding throughput will find increasing application for in vivo nutrition experiments (Ferrer et al., 2005). A challenge in these types of studies will be to separate functionally important genes of bacterial origin from those of protozoal origin, given that there seems to be horizontal gene transfer from bacteria into rumen protozoa (Ricard et al., 2006). For example, Newbold et al. (2005) recently derived evidence to suggest that protozoa can directly incorporate ammonia via glutamate dehydrogenase. Because $\mathrm{NH}_{3}-\mathrm{N}$ assimilation into protozoal $\mathrm{N}$ has been assumed to be through bacterial $\mathrm{N}$ (Koenig et al., 2000), the functional significance of this finding currently is not known. Clearly, the rumen protozoa-bacteria interactions need much more attention in the future to correlate ruminal numbers (and perhaps biomass) of protozoa and bacteria with microbial degradation of feed protein and MPS in the rumen.

\section{Protozoal and Bacterial AA Metabolism}

Mixed ruminal bacteria require an appropriate mix of AA for optimal growth, and the extrapolation of the limiting AA paradigm associated with animal nutrition to ruminal bacteria is probably not appropriate. For example, no single AA deletion decreased bacterial EMPS (Guliye et al., 2005) as much as would be expected, and increasing supply of certain AA can overcome apparent antagonisms associated with high amounts of specific AA (Kajikawa et al., 2005). Anaerobic bacteria from ecosystems outside of the rumen can regulate the gene expression of key enzymes involved 

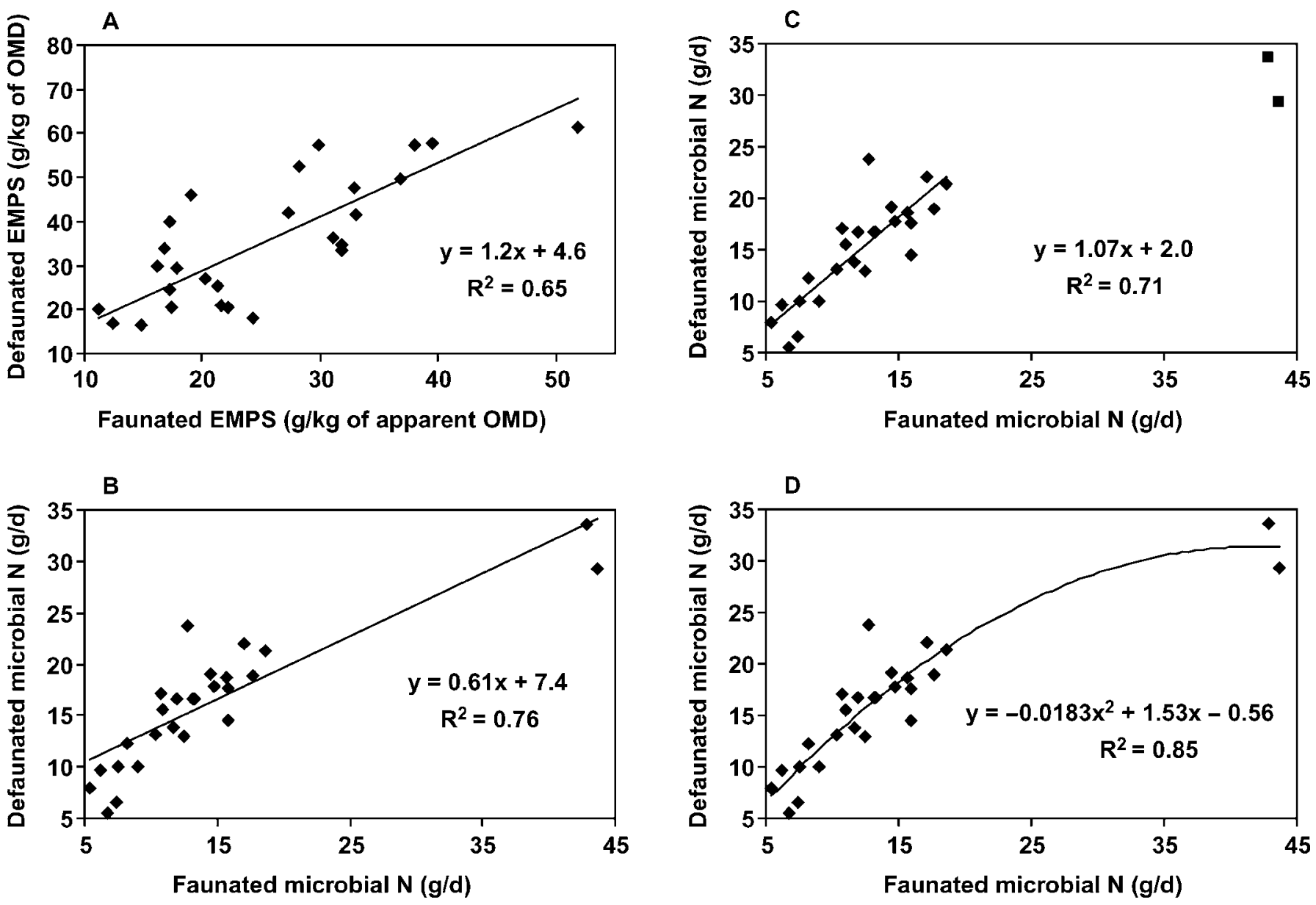

Figure 1. Relationships between means from data in multiple trials in which sheep were faunated or defaunated. Panel A shows a constant relationship reported for efficiency of microbial protein synthesis [EMPS; $g$ of microbial $\mathrm{N}$ flowing to the duodenum per kg of OM truly digested (OMD) in the rumen]. Panel B shows the reported relationship for duodenal flow of microbial N. However, if the 2 high points are omitted, then the slope becomes greater than 1 (panel C). If a quadratic polynomial is evaluated (panel D), the intercept was $P>0.05$ from zero, but the $\mathrm{x}^{2}$ coefficient was $P<0.001$ from zero. Data from Hristov and Jouany (2005).

in protein degradation and synthesis to maintain an optimal intracellular concentration of AA (Chambellon and Yvon, 2003). Although not directly supporting this conclusion, the rumen bacterial AA pool size seems to remain approximately constant in cattle fed widely different diets (Ives et al., 2002). The AA synthesized from carbon skeletons and ammonia assimilation into bacterial $\mathrm{N}$ varies across diets (Bach et al., 2004). De novo synthesis of AA can involve competing flux of Krebs cycle intermediates (even if anaerobic bacteria do not have a complete cycle) in both the forward and reverse directions, depending on the AA being synthesized (Walker et al., 2005). Therefore, the flux of individual AA must be regulated with the need for specific AA for protein synthesis and with the availability of hexoses and perhaps other carbon sources for de novo synthesis of nonprotein cell components as well as with consideration to balancing reducing equivalents (which could influence flux of carbon skeletons in metabolism).

The ramifications of integrating bacterial AA needs with protozoal mediation of AA degradation are not well known. Protozoa can use AA from RDP as well as from consumed bacteria. However, the high AA concentration of bacteria seems to make bacterial AA a preferred protein source; that is, bacterial protein might be more consistently available than dietary RDP, so have protozoa simply adapted to use the more consistent source relatively inefficiently and even when there is plenty of RDP? The rate of bacterial degradation by protozoa seems to vary with the bacterial cell wall structure, extracellular matrix, and other factors (Walker et al., 2005). Thus, the excretion of large amounts of partially degraded bacterial proteins into the rumen probably influences the abundance and perhaps type of AA-degrading bacteria that are pres- 
ent. There seem to be 2 predominant groups of bacteria contributing to AA catabolism (i.e., the highly abundant but low activity proteolytics vs. the low number but high activity AA degraders), and there might be more interaction among these groups than previously thought (Eschenlauer et al., 2002). Monensin (Eschenlauer et al., 2002) and essential oils (Newbold et al., 2004) are 2 additives that inhibit deaminating bacterial populations independent of, or concomitant with, their effects on protozoa. Moreover, adaptive defenses to predation or defaunation agents by hyperammonia producers (Walker et al., 2005) should be studied. Consequently, metagenomics approaches might be needed, rather than using direct treatments, to more fully understand the complexity of AA metabolism in the rumen.

It is not known if protozoa (which have high deaminase activity; Walker et al., 2005) compete with deaminating bacteria for AA or through predation of hyperammonia-producing bacteria or, in contrast, if they stimulate them by secreting incompletely degraded proteins. There is probably greater diversity among groups of hyperammonia-producing bacteria based on genomics compared with culture-based techniques (Eschenlauer et al., 2002); consequently, although AA would be soluble, the activity of these hyperammoniaproducing bacteria need not be confined to the liquidassociated bacteria, which conventionally have been considered to be more likely to be predated than those attaching to starch granules (Williams and Coleman, 1992). Recent studies by Larue et al. (2005) and Yu et al. (2006) have shown that many of the eubacteria tightly adherent to plant biomass in the rumen are novel lineages representing the Firmicutes phylum that are most closely related to clostridial species known to utilize AA and peptides, so these bacteria would presumably have decreased deaminase activity in the rumen. Conversely, does protozoal ingestion of starch (the major energy source for adherent saccharolytic bacteria that are also proteolytic) indirectly favor the hyperammonia-producing bacteria? These studies would be enabled by the use of one or a combination of real-time PCR assays targeting these groups and further attention to other considerations (e.g., gene copies per cell, PCR efficiency, extracting bacterial DNA from fluid vs. plant particulate fractions) that have been described previously (Firkins and Yu, 2006) or will be described subsequently.

\section{Quantification of Protozoal Biomass in the Rumen and Duodenum}

Because much of the pioneering work with ruminal protozoa was done with sheep, whereas differences in digestive physiology might limit extension of these data for dairy cattle, we consider it important to break down the potential effects of protozoa and reconsider their role on the microbial ecosystem of the dairy cow. When simulating increasing substrate supply with increasing DMI such as would be seen with dairy cattle, decreasing ruminal $\mathrm{pH}$ and increasing $\mathrm{kp}$ decreased the ruminal pool size of protozoa relative to that of bacteria (Dijkstra et al., 1998b); however, a limitation of that model is that few experimentally derived corroborative data are available to challenge the equations when extrapolated to dairy conditions of high DMI and fast kp.

As explained previously (Firkins and Yu, 2006), expectations by many researchers are for protozoal biomass to be much higher in the rumen relative to the amount of outflow. In contrast, Sylvester et al. (2005), using a real-time PCR assay, noted similar protozoal biomass as a proportion of the total microbial biomass in the rumen compared with the duodenum. Skillman et al. (2006) reported good agreement with their realtime PCR assay for protozoa compared with protozoal counts, particularly when PCR efficiencies were close to 2 (i.e., each copy is doubled in each PCR cycle). These data were not reported by Sylvester et al. (2004), but we note here that our efficiencies ranged from 1.95 to 1.99. In fact, PCR efficiency can profoundly influence meta-analyses of microbial populations (Firkins and $\mathrm{Yu}, 2006$ ). The Skillman et al. (2006) report used primers specific for Entodinium and Dasytricha. The latter genus was not always quantifiable because of their low numbers, but the predominant entodinia showed a good relationship between counts and copies of rRNA genes. Although these PCR procedures require standardization against counts or biomass of a harvested protozoa standard because the rRNA gene copies vary per cell under different growth conditions (Sylvester, 2005), they clearly have promise to quantify specific protozoal populations and to discern any potential niches of individual populations in dairy cattle. Both studies also clearly identify large differences in protozoal populations among animals; if these differences can be related to $\mathrm{N}$ metabolism, then perhaps efforts can be directed toward selection for, or suppression of, specific functional groups of protozoa among different animals.

Quantifying the biomass of various populations is important to furthering our understanding of the role of protozoa in ruminal $\mathrm{N}$ metabolism. Isotrichids are presumed to have a minor effect on flow of bacterial $\mathrm{N}$ to the duodenum compared with the entodiniomorphids (Ivan et al., 2000a). Similarly, even though entodiniomorphids improved ruminal NDF digestibility, the bacterial $\mathrm{N}$ flow was greatly reduced (Ivan et al., 
$2000 \mathrm{~b})$. The latter authors' stated limitations of diaminopimelic acid as a bacterial flow marker. In addition, because protozoa metabolize diaminopimelic acid to lysine (Walker et al., 2005), one has to wonder if defaunation increased the outflow of unmetabolized marker from bacterial cell wall fragments. In a rare study with dairy cattle, Yang and Varga (1993) pair-fed a control or sufficient continuously dosed antiprotozoal agent to keep them defaunated. Microbial $\mathrm{N}$ flows were not reported, but milk protein concentration was increased by defaunation. Ruminal fiber degradation and solids $\mathrm{kp}$ were decreased. However, numerous studies suppressing protozoal populations with various antiprotozoal agents have shown relatively consistent results (although variable in magnitude) in which lowered NDF or OM digestibility in the rumen have been compensated by higher EMPS (Eugène et al., 2004; Hristov and Jouany, 2005). Unfortunately, it might not be possible to completely separate the effect of defaunation from the residual effects of the defaunation agent.

\section{Considerations for Protozoa-Mediated N Turnover}

Expectations for high protozoal autolysis in the rumen (Dijkstra et al., 1998b) are supported by in vitro studies in which extracted protozoa could be stressed by harvesting procedures or longer term cultures in which bacterial overgrowth is prevented by feeding once per day. More mechanistic work with nonrumen protozoa has documented that the control mechanism for chemotaxis appears to be signaled by decreasing cyclic nucleotide-activated protein kinases (Baker and Deng, 2005; Kissmehl et al., 2006). These kinases can be grouped into families of genes in the microbial world and even in higher eukaryotes (Baker and Kelly, 2004; Kissmehl et al., 2006). With such profound diversity in function of these signaling mechanisms, it seems inconsistent for traditional expectations of such high autolysis in rumen protozoa. The isotrichids stop chemotaxis toward sugars when they are full of internal polysaccharide (Dehority and Tirabasso, 1989). Although entodiniomorphids incubated in vitro have been observed to continue to try to actively take up starch even when full, they also are chemotactically attracted to fine fiber particles and starch grains (Williams and Coleman, 1992). Assuming a similar signaling response to suppress chemotaxis when full of internal polysaccharide as described for isotrichids (and which seems to be highly conserved in nonrumen protozoa), this phenomenon of excessive lysis of entodiniomorphs in vitro might be less likely to occur in vivo because of more intermittent eating patterns, larger grain particles, more competition for the starch by bacteria, or perhaps other factors found in their natural environment. In support of this argument, there actually is limited experimental evidence directly supporting extensive protozoal autolysis (Dehority, 1998). Ankrah et al. (1990) incubated protozoa inside a chamber with retaining filters inside the rumen. The counts of protozoa in the rumen declined by $33 \%$ after feeding but only by $17 \%$ in the container. Thus, they estimated that about $16 \%$ of the decrease in counts was a result of lysis and $17 \%$ a result of dilution in concentration by feeding and drinking.

In vivo-based expectations for autolysis associated with very long generation times associated with settling and sequestration of isotrichid protozoa in the ventral reticulorumen (Leng and Nolan, 1984; Dijkstra et al., 1998b) can, in part, be rooted to a series of studies in which they were labeled with ${ }^{14} \mathrm{C}$-choline. A major advantage of this type of technique is that, theoretically, the labeled protozoa are tracing their respective populations in their natural environment; the major disadvantage is that the labeling process removes them from their natural environment and can potentially influence the results (Brock, 1971). For example, even centrifugation at $200 \times g$ can markedly decrease motility and apparent viability of protozoa (Kisidayova et al., 2005), and repeated centrifugation was used in the ${ }^{14} \mathrm{C}$-choline labeling process. Indeed, Leng et al. (1981) noted a biphasic specific activity vs. time curve. The protozoal irreversible loss rate averaged $2.8 \mathrm{~g} / \mathrm{d}$ if the first phase of the curve was used. However, from data also presented in that paper, we calculated that the irreversible loss rate would be 12.4 $\mathrm{g} / \mathrm{d}$ if the later phase were used. Moreover, the specific activity was presented as ${ }^{14} \mathrm{C}$ radioactivity units per mass of $\mathrm{N}$ in harvested protozoal samples primarily containing large isotrichids. If the total isotrichid pool in the rumen were presumed to be constant (i.e., a steady state in the mass of protozoal N), then the loss in activity would be reflected only by loss of the radiolabel (i.e., of the dosed isotrichids). Because their labeling procedure removed these protozoa for several hours to incubate them with ${ }^{14} \mathrm{C}$-choline and wash the cells before dosing back into the rumen, a logical concern would be if that procedure inhibited protozoal function. Their criterion for judging protozoal function was observed normal motility. They assumed that the first phase of the curve would represent normal protozoal function and the second phase would represent cell lysis of protozoa resulting from the labeling process. However, if the second phase were a result of lysis, then why would such a biological response have such a discrete break point? Williams and Coleman (1992) elaborated on the challenges of culturing isotrichids. Karnati et al. (2006) noted that isotrichids 
are very difficult to establish in continuous culture from a normal ruminal fluid inoculum that was dosed into fermenters in $<30 \mathrm{~min}$ after its collection. Therefore, a potential alternative conclusion might be that the labeling technique could blunt isotrichid cell division after reintroduction into the rumen; perhaps, after a period of reestablishment, cell growth rate of the dosed protozoa could have reinitiated. As explained later, the cell cycle of individual protozoal cells is discrete, so such a phenomenon could explain the biphasic turnover of the label in the Leng et al. (1981) study.

Firkins and $\mathrm{Yu}$ (2006) further discussed the potential that rapid sinking to the ventral locations of the reticulorumen does not prove that isotrichids are totally sequestered in the rumen. When they migrate back to the more dorsal locations after feeding, these populations of isotrichids are underrepresented in the ventral locations and thus would have compensatory potential for passage. Second, they also discussed the concept that differential generic counts of isotrichids (as a percentage of total counts) should be much lower in the omasum than in the rumen if they are selectively retained in the rumen, and available data do not support this argument.

Even accounting for the large size of Isotricha would not typically affect dairy cattle metabolism much because most reports have $<1 \%$ of the total counts (including the smaller Dasytricha) as isotrichids in typical dairy rations that contain little fresh pasture or sugars. Still, this perception of a large impact of isotrichid sequestration seems to imprint the same (but not necessarily accurate) expectation for high sequestration of all protozoa in the rumen, and protozoal turnover measurements simply are lacking in the high-producing dairy cow. Combining the ${ }^{14} \mathrm{C}$-choline labeling technique with quantitative assessments of microbial $\mathrm{N}$ in beef cattle and sheep at relatively low DMI, Punia et al. (1992) determined that protozoal N averaged $68 \%$ of the total $\mathrm{N}$ (including feed N, so the value is clearly too high) in the rumen. They arbitrarily reduced this value by $30 \%$, but recently Sylvester et al. (2005) determined that $47.5 \%$ of the total $\mathrm{N}$ in protozoa harvested using a sedimentation technique similar to that of Punia et al. (1992) was actually $\mathrm{N}$ from contaminating bacteria. If we assume that the measured $\mathrm{N}$ in their harvested protozoal samples was diluted by $47.5 \%$ with contaminating bacteria (i.e., those bacteria that easily wash through filter pores and are not exoor endosymbionts with protozoa), their specific activity units (radioactivity of ${ }^{14} \mathrm{C}$ per unit of total $\mathrm{N}$ ) would likely be consistently underestimated, and their pool size of protozoa would then be approximately $36 \%$. This discussion reemphasizes the need for more accu- rate measurement of ruminal protozoal pool size relative to protozoal $\mathrm{N}$ outflow for better quantitative understanding of the role of protozoa in $\mathrm{N}$ metabolism in dairy cattle.

Bacterial consumption and degradation by protozoa is well documented (Hristov and Jouany, 2005), and predation of bacteria is probably the most important factor influencing bacterial lysis in the rumen (Wallace and McPherson, 1987). However, the relative amount of the entire bacterial $\mathrm{N}$ pool being consumed by protozoa in vivo, particularly in the dairy cow, could be less than previously thought. Bacterial predation seems to be mediated through continuous bacterial grazing such that the amount of bacteria actually consumed by protozoa is inversely proportional to the amount of starch granules consumed (Hristov and Jouany, 2005). Although not understood, the process could be a simple limitation of intracellular space or a more mechanistic function (e.g., endo- and exocytosis in protozoa seem to be mediated through protein kinase G; Kissmehl et al., 2006).

Dijkstra (1994) developed a mathematical model based largely on data from in vitro studies. This model is very sensitive to parameters describing bacterial engulfment rate, protozoal maintenance requirement, and protozoal lysis rates. To prevent an excessively high predicted ruminal pool size of protozoa, the growth rate must be tempered by lysis rate. Because parameterization of the protozoa model was based on in vitro experiments or in vivo experiments with protozoa exogenously labeled with ${ }^{14} \mathrm{C}$-choline (see previous discussion regarding limitations of this approach), we suggest an alternative viewpoint to extensive lysis in the rumen to moderate the predicted protozoal pool size. Perhaps protozoa simply wash out of the rumen of dairy cattle faster than previously thought because of their faster ruminal kp. To justify this hypothesis, we need to better understand the biological factors influencing protozoal growth, lysis, and outflow.

\section{Protozoal Growth Rate, Chemotaxis, and Lysis}

Recent work from our laboratory (Sylvester, 2005) has shown that protozoal cultures rapidly adjust their generation time to approximate the time between transfers. These results are consistent with previous work in which generation time decreased with decreasing transfer time (Dehority, 1998) and when amount of substrate was manipulated (Dehority, 2004). Therefore, at least part of the variation in generation time of protozoa seems to be related to passage rate independent of substrate supply. Karnati et al. (2007) calculated the pool size of total protozoa in the rumen and divided that by the omasal flow of total protozoal 
cells to obtain generation times averaging $16.4 \mathrm{~h}$. This average generation time was comparable with protozoal $\mathrm{N}$ turnover time determined using a real-time PCR assay (Sylvester et al., 2005) both of which were done with high-producing dairy cattle. These latter 2 studies document that the passage rate of protozoa approximates that of the feed particles and is slower than that of the ruminal fluid. This does not necessarily mean that passage is because of attachment to particles, which, although often discussed, is not particularly common in the rumen (Dehority, 1998).

In a series of in vitro experiments (Dehority, 1998; Fondevila and Dehority, 2001; Dehority, 2004) with decreasing transfer times, the generation time of various protozoal species has typically been able to be reduced to approximately $12 \mathrm{~h}$. These values are based on cell counts, so protozoal autolysis would already be factored in (i.e., this is a net generation of protozoal growth minus lysis of cells, which obviously do not undergo further cell division). Furthermore, these are from discontinuous transfers as opposed to more continuous feeding and a more continual opportunity for passage in vivo. In contrast with bacteria, which have short division times, protozoa undergo eukaryotic cell cycles with discrete phases that are highly regulated (Berger, 2001). The rumen is probably composed of a distribution of protozoa each with discrete cell cycles but for which the distribution smoothes out the entire population's growth curve. This growth pattern might not be totally simulated in batch culture situations with discontinuous feeding and transfers.

Protozoa are often described as needing to sequester in the rumen because of their slow growth rate on a cell basis, but this is misleading because numerous generations of bacteria would be needed to produce a similar amount of biomass to that comprising a single division of a much larger protozoan cell. In one study from Sylvester (2005), Epidinium caudatum had approximately 5 times more biomass per cell than did Entodinium caudatum. When using the procedure described by Warner (1962) in which dividing forms of protozoa are measured between feedings, the larger cells took approximately 5 times longer to complete the division process than did the smaller forms (J. T. Sylvester and J. L. Firkins, Ohio State University, Columbus; unpublished data). Yet the overall division time of both species seemed to be closely matched with transfer time (Sylvester, 2005). In contrast with protozoal growth probably being related to substrate supply relative to protozoal biomass, protozoal passage from the rumen is probably a function of cell numbers. Consequently, we suggest that the excessive bacterial predation and inefficiency of $\mathrm{N}$ usage determined in vitro becomes less and less problematic with high-producing dairy cattle with faster $\mathrm{kp}$ effluxing protozoa more rapidly. The higher $\mathrm{kp}$ is coupled with greater substrate supply (higher DMI) in numerous meals per day, which presumably should fill protozoa with starch and other substrates relative to bacterial grazing, which is a slow, continual process (Hristov and Jouany, 2005). Thus, there could be less lysis of protozoa in vivo than in vitro, faster passage, lower ruminal pool size of protozoa relative to bacteria, and improved efficiency of protozoal cell growth (faster cell division); consequently, there could be less recycling of predated bacteria relative to the amount protozoa passing from the rumen for dairy cattle compared with most previously studied ruminants.

\section{Dietary Supplements to Suppress Protozoa in Dairy Cattle}

A common way to suppress protozoal numbers is to feed dietary fat, although these effects are variable, depending on the type of fat and other factors (Hristov and Jouany, 2005). The isotrichids seem to be more sensitive to fat than the cellulolytic protozoa, which could be more sensitive than the smaller entodinia (Ivan et al., 2001). The depression of protozoal counts by dietary oil was enhanced with decreasing forage concentration, and this combination also increased the duodenal flow of trans-10 18:1 (Ueda et al., 2003; Loor et al., 2004). In the studies of Oldick and colleagues (Oldick and Firkins, 2000; Oldick et al., 2000), EMPS was increased by feeding fat sources differing in saturation. The recycling of microbial $\mathrm{N}$ through the $\mathrm{NH}_{3}$ $\mathrm{N}$ pool decreased linearly with increasing unsaturation of fat; however, the average value was nearly the same as the control treatment without fat, and recycling values were not correlated with EMPS. Total protozoa counts only tended to be decreased with increasing fat unsaturation. Only the counts of isotrichids $(<0.6 \%$ of total counts) were significantly correlated with EMPS (but not entodiniomorphids or total counts). Given that the predatory nature of isotrichids should be less than that of the entodiniomorphids (see earlier discussion), the meaning of this correlation is not clear. Some of the lack of distinction could be related to variability in measurement of protozoal counts and the inconsistency between cell count and cell size, justifying a need for better quantification methods for microbial biomass (see earlier discussion). Therefore, factors other than protozoal excretion of consumed bacterial protein should be explored as alternative explanations for changing EMPS, particularly when using dietary fat to suppress protozoal populations.

With the approval of monensin for dairy rations, there has been renewed interest in studying ruminal 
effects, particularly because protozoa seem to adapt to it (Guan et al., 2006) and because it likely influences biohydrogenation intermediates flowing to the duodenum (Firkins et al., 2006). When culturing bacteria, monensin would be strongly inhibitory to many bacteria initially and they would become extinct in culture; however, in the rumen, there could be constant reinoculation of bacteria or stratification of monensin concentrations, and there should be increasing abundance of subpopulations or strains that are relatively insensitive (Callaway and Russell, 1999; Walker et al., 2005). Increasing insensitivity to monensin is not likely mediated by gene transfer (Russell and Houlihan, 2003). Consequently, adaptation by bacteria (Callaway et al., 1999; Callaway and Russell, 2000) and protozoa (Nagaraja et al., 1997; Guan et al., 2006) is more likely a consequence of physiological adaptation(s) to surface architecture. Researchers should consider taking repeated long-term samples to evaluate adaptation to monensin (Sauer et al., 1998). We should expect such adaptations in the bacterial lipid composition of the cell wall from gene transcription (Schujman and de Mendoza, 2005) or even as a shortterm stress response at the enzyme activity level (Beales, 2003). It is possible that even the act of harvesting bacteria could increase the trans fatty acid concentration of the cell membrane (Härtig et al., 2005). Because of the potential importance for bacterial fatty acid concentration as a criterion to characterize the bacterial populations (Vlaemink et al., 2006), the time before harvesting or stabilization (e.g., through lyophilization) of ruminal bacteria should be rapid.

Numerous other methods have been studied with regard to potential antiprotozoa properties (Hristov and Jouany, 2005). However, these have not received much attention with dairy cattle, particularly with longer term feeding, and will not be discussed.

\section{CONCLUSIONS}

Metagenomics approaches are becoming increasingly cost- and time-effective tools to integrate rumen microbial ecology with nutrition. Although digesta samples can be stored for future analyses, researchers should still consider these approaches a priori to design experimental hypotheses and protocols to account for ruminal stratification of digesta contents, postprandial changes in microbial populations, and longer term adaptation of microbial membrane composition. Although these approaches can help explain differences in microbial community structure among different animals, we caution that variables calculated using common measurements could potentially bias re- gressions using individual animals. There has been much progress by evaluating flux of ruminal $\mathrm{NH}_{3}-\mathrm{N}$ in different dietary conditions. However, future research needs to combine these quantitative approaches with more knowledge on AA degradation and uptake into microbial protein, particularly for the dairy cow with such a high DMI and ruminal kp. Enhanced understanding of protozoa-bacteria interactions through competition for nitrogenous precursors or via the predator-prey relationship might provide key missing data in these future studies. We suggest that the efficiency of ruminal $\mathrm{N}$ usage in dairy cattle might be improved more effectively through these objectives than by continued efforts to defaunate or suppress protozoal abundance below levels at which the loss in beneficial functions of protozoa outweigh their negative aspects from bacterial predation. Through increased understanding of the total microbial ecosystem, ruminant nutritionists should help improve the overall efficiency of $\mathrm{N}$ usage in dairy cattle under varied dietary conditions.

\section{REFERENCES}

Ankrah, P., S. C. Loerch, and B. A. Dehority. 1990. Sequestration, migration and lysis of protozoa in the rumen. J. Gen. Microbiol. 136:1869-1875.

Bach, A., S. Calsamiglia, and M. D. Stern. 2004. Nitrogen metabolism in the rumen. J. Dairy Sci. 88(E Suppl.):E9-E21.

Baker, D. A., and W. Deng. 2005. Cyclic GMP-dependent protein kinases in protozoa. Front. Biosci. 10:1229-1238.

Baker, D. A., and J. M. Kelly. 2004. Structure, function, and evolution of microbial adenylyl and guanylyl cyclases. Mol. Microbiol. 52:1229-1242.

Bateman, H. G., and T. C. Jenkins. 1998. Influence of soybean oil in high fiber diets fed to nonlactating cows on ruminal unsaturated fatty acids and nutrient digestibility. J. Dairy Sci. 81:2451-2458.

Beales, N. 2003. Adaptation of microorganisms to cold temperatures, weak acid preservatives, low $\mathrm{pH}$, and osmotic stress: A review. Comp. Rev. Food Sci. Food Safety 3:1-20.

Berger, J. D. 2001. Riding the ciliate cell cycle-A thirty-five-year prospective. J. Euk. Microbiol. 48:505-518.

Brock, T. D. 1971. Microbial growth rates in nature. Bacteriol. Rev. 35:39-58.

Brown, M. S., C. H. Ponce, and R. Pulikanti. 2006. Adaptation of beef cattle to high-concentrate diets: Performance and ruminal metabolism. J. Anim. Sci. 84(E Suppl.):E25-E33.

Callaway, T. R., K. A. Adams, and J. B. Russell. 1999. The ability of "low G + C gram-positive" ruminal bacteria to resist monensin and counteract potassium depletion. Curr. Microbiol. 39:226230.

Callaway, T. R., and J. B. Russell. 1999. Selection of a highly monensin-resistant Prevotella bryantii subpopulation with altered outer membrane characteristics. Appl. Environ. Microbiol. 65:4753-4759.

Callaway, T. R., and J. B. Russell. 2000. Variations in the ability of ruminal gram-negative Prevotella species to resist monensin. Curr. Microbiol. 40:185-189.

Chambellon, E., and M. Yvon. 2003. CodY-regulated aminotransferases AraT and BcaT play a major role in the growth of Lactococcus lactis in milk by regulating the intracellular pool of amino acids. Appl. Environ. Microbiol. 69:3061-3068.

Dehority, B. A. 1998. Generation times of Epidinium caudatum and Entodinium caudatum, determined in vitro by transferring at various time intervals. J. Anim. Sci. 76:1189-1196. 
Dehority, B. A. 2003. Rumen Microbiology. Nottingham University Press, Nottingham, UK.

Dehority, B. A. 2004. In vitro determination of generation times for Entodinium exiguum, Ophryoscolex purkynjei, and Eudiplodinium maggii. J. Euk. Microbiol. 51:333-338.

Dehority, B. A., and P. A. Tirabasso. 1989. Factors affecting the migration and sequestration of rumen protozoa in the family Isotrichidae. J. Gen. Microbiol. 135:539-548.

Dijkstra, J. 1994. Simulation of the dynamics of protozoa in the rumen. Br. J. Nutr. 72:679-699.

Dijkstra, J., J. France, and D. R. Davies. 1998a. Different mathematical approaches to estimating microbial protein supply in ruminants. J. Dairy Sci. 81:3370-3384.

Dijkstra, J., J. France, and S. Tamminga. 1998b. Quantification of the recycling of microbial nitrogen in the rumen using a mechanistic model of rumen fermentation processes. J. Agric. Sci. 130:81-94.

Dijkstra, J., E. Kebreab, A. Bannink, J. France, and S. López. 2005. Application of the gas production technique to feed evaluation systems for ruminants. Anim. Feed Sci. Technol. 123124:561-578.

Dijkstra, J., and S. Tamminga. 1995. Simulation of the effects of diet on the contribution of rumen protozoa to degradation of fibre in the rumen. Br. J. Nutr. 74:617-634.

Edwards, J. E., N. R. McEwan, A. J. Travis, and R. J. Wallace. 2004. 16S rDNA library-based analysis of ruminal bacterial diversity. Antonie Van Leeuwenhoek 86:263-281.

Eschenlauer, S. C. P., N. McKain, N. D. Walker, N. R. McEwan, C. J. Newbold, and R. J. Wallace. 2002. Ammonia production by ruminal microorganisms and enumeration, isolation, and characterization of bacteria capable of growth on peptides and amino acids from the sheep rumen. Appl. Environ. Microbiol. 68:4925-4931.

Eugène, M., H. Archimède, and D. Sauvant. 2004. Quantitative meta-analysis on the effects of defaunation of the rumen on growth, intake and digestion in ruminants. Livest. Prod. Sci. 85:81-97.

Ferrer, M., O. V. Golyshina, T. N. Chernikova, A. N. Khachane, D. Reyes-Duarte, V. A. P. Martins Dos Santos, C. Strömpl, K. Elborough, G. Jarvis, A. Neef, M. M. Yakimov, K. N. Timmis, and P. N. Golyshin. 2005. Novel hydrolase diversity retrieved from a metagenome library of bovine rumen microflora. Environ. Microbiol. 7:1996-2010.

Firkins, J. L. 1996. Maximizing microbial protein synthesis in the rumen. J. Nutr. 126:1347S-1354S.

Firkins, J. L., M. S. Allen, B. S. Oldick, and N. R. St-Pierre. 1998. Modeling ruminal digestibility of carbohydrates and microbial protein flow to the duodenum. J. Dairy Sci. 81:3350-3369.

Firkins, J. L., M. L. Eastridge, N. R. St-Pierre, and S. M. Noftsger. 2001. Effects of grain variability and processing on starch utilization by lactating dairy cattle. J. Anim. Sci. 79(E Suppl.):E218-E238.

Firkins, J. L., A. N. Hristov, M. B. Hall, G. A. Varga, and N. R. StPierre. 2006. Integration of ruminal metabolism in dairy cattle. J. Dairy Sci. 89(E Suppl.):E31-E51.

Firkins, J. L., S. M. Lewis, L. Montgomery, L. L. Berger, N. R. Merchen, and G. C. Fahey. 1987. Effects of feed intake and dietary urea concentration on ruminal dilution rate and efficiency of bacterial growth in steers. J. Dairy Sci. 70:2312-2321.

Firkins, J. L., and C. K. Reynolds. 2005. Whole animal nitrogen balance in cattle. Pages 167-185 in Nitrogen and Phosphorus Nutrition of Cattle and Environment. E. Pfeffer and A. Hristov, ed. CAB International, Cambridge, MA.

Firkins, J. L., and Z. Yu. 2006. Characterisation and quantification of the microbial populations in the rumen. Pages 19-54 in Ruminant Physiology, Digestion, Metabolism and Impact of Nutrition on Gene Expression, Immunology and Stress. K. Sejrsen, T. Hvelplund, and M. O. Nielsen, ed. Wageningen Academic Publishers, Wageningen, the Netherlands.

Fondevila, M., and B. A. Dehority. 2001. In vitro growth and starch digestion by Entodinium exiguum as influenced by the presence or absence of live bacteria. J. Anim. Sci. 79:2465-2471.
Fox, D. G., L. O. Tedeschi, T. P. Tylutki, J. B. Russell, M. E. Van Amburgh, L. E. Chase, A. N. Pell, and T. R. Overton. 2004. The Cornell net carbohydrate and protein system for evaluating herd nutrition and nutrient excretion. Anim. Feed Sci. Technol. 112:29-78.

Galperin, M. Y. 2004. Metagenomics: From acid mine to shining sea. Environ. Microbiol. 6:543-545.

Griswold, K. E., G. A. Apgar, J. Bouton, and J. L. Firkins. 2003. Effects of urea infusion and ruminal degradable protein concentration on microbial growth, digestibility, and fermentation in continuous culture. J. Anim. Sci. 81:329-336.

Guan, H., K. M. Wittenberg, K. H. Ominski, and D. O. Krause. 2006. Efficacy of ionophores in cattle diets for mitigation of enteric methane. J. Anim. Sci. 84:1896-1906.

Guliye, A. Y., G. Atasoglu, and R. J. Wallace. 2005. Assessment of amino acid requirements for optimum fermentation of xylan by mixed micro-organisms from the sheep rumen. Anim. Sci. 80:353-360.

Härtig, C., N. Loffhagen, and H. Harms. 2005. Formation of trans fatty acids is not involved in growth-linked membrane adaptation of Pseudomonas putida. Appl. Environ. Microbiol. 71:1915-1922.

Harvatine, K. J., and M. S. Allen. 2006. Fat supplements affect fractional passage rates of ruminal fatty acid biohydrogenation and passage in dairy cows. J. Nutr. 136:677-685.

Harvatine, D. I., J. E. Winkler, M. Devant-Guille, J. L. Firkins, N. R. St-Pierre, and M. L. Eastridge. 2002. Whole linted cottonseed as a forage substitute: Fiber effectiveness and digestion kinetics. J. Dairy Sci. 85:1988-1999.

Hoover, W. H. 1986. Chemical factors involved in ruminal fiber digestion. J. Dairy Sci. 69:2755-2766.

Hristov, A. N., K. L. Grandeen, J. K. Ropp, and M. A. McGuire. 2004. Effect of sodium laurate on ruminal fermentation and utilization of ruminal ammonia nitrogen for milk protein synthesis in dairy cows. J. Dairy Sci. 87:1820-1831.

Hristov, A. N., and J.-P. Jouany. 2005. Factors affecting the efficiency of nitrogen utilization in the rumen. Pages 117-166 in Nitrogen and Phosphorus Nutrition of Cattle and Environment. A. N. Hristov and E. Pfeffer, ed. CAB International, Wallingford, UK.

Hristov, A. N., J. K. Ropp, K. L. Grandeen, S. Abedi, R. P. Etter, A. Melgar, and A. E. Foley. 2005. Effect of carbohydrate source on ammonia utilization in lactating dairy cows. J. Anim. Sci. 83:408-421.

Huhtanen, P. 2005. Critical aspects of feed protein evaluation systems for ruminants. J. Anim. Feed Sci. 14(Suppl. 1):145-170.

Isaacson, H. R., F. C. Hinds, M. P. Bryant, and F. N. Owens. 1975. Efficiency of energy utilization by mixed rumen bacteria in continuous culture. J. Dairy Sci. 58:1645-1659.

Ivan, M., P. S. Mir, K. M. Koenig, L. M. Rode, L. Neill, T. Entz, and Z. Mir. 2001. Effects of dietary sunflower seed oil on rumen protozoa population and tissue concentration of conjugated linoleic acid in sheep. Small Rumin. Res. 41:215-227.

Ivan, M., L. Neill, and T. Entz. 2000a. Ruminal fermentation and duodenal flow following progressive inoculations of fauna-free wethers with major individual species of ciliate protozoa or total fauna. J. Anim. Sci. 78:750-759.

Ivan, M., L. Neill, R. Forster, R. Alimon, L. M. Rode, and T. Entz. 2000b. Effects of Isotricha, Dasytricha, Entodinium, and total fauna on ruminal fermentation and duodenal flow in wethers fed different diets. J. Dairy Sci. 83:776-787.

Ives, S. E., E. C. Titgemeyer, and T. G. Nagaraja. 2002. Technical note: Effect of removal of microbial cells by centrifugation on peptide and $\alpha$-amino nitrogen concentrations in ruminal fluid. J. Dairy Sci. 85:3059-3061.

Kajikawa, H., M. Mitsumori, K. Tajima, and M. Kurihara. 2005. Amino acids antagonistic to the amino acids inhibitory for growth rate of mixed ruminal bacteria. J. Dairy Sci. 88:26012603.

Karnati, S. K. R., J. T. Sylvester, L. E. Gilligan, and J. L. Firkins. 2006. Manipulation of fermentation profile and methane produc- 
tion with microbial inhibitors and protozoal retention in continuous culture. J. Dairy Sci. 89(Suppl. 1):127-128. (Abstr.)

Karnati, S. K. R., J. T. Sylvester, S. M. Noftsger, Z. Yu, N. R. StPierre, and J. L. Firkins. 2007. Adapting molecular techniques and omasal sampling to assess changes in ruminal bacterial populations and protozoal generation time in cows fed different methionine sources. J. Dairy Sci. 90:798-809.

Kisidayova, S., Z. Varadyova, T. Michalowski, and C. J. Newbold. 2005. Regeneration of cryoresistance of in vitro rumen ciliate cultures. Cryobiology 51:76-84.

Kissmehl, R., T. P. Krüger, T. Treptau, M. Froissard, and H. Plattner. 2006. Multigene family encoding 3',5'-cyclic-GMP-dependent protein kinases in Paramecium tetraurelia cells. Eukaryot. Cell 5:77-91.

Klusmeyer, T. H., R. D. McCarthy, Jr., J. H. Clark, and D. R. Nelson. 1990. Effects of source and amount of protein on ruminal fermentation and passage of nutrients to the small intestine of lactating cows. J. Dairy Sci. 73:3526-3537.

Koenig, K. M., C. J. Newbold, F. M. McIntosh, and L. M. Rode. 2000. Effects of protozoa on bacterial nitrogen recycling in the rumen. J. Anim. Sci. 78:2431-2445.

Larue, R., Z. Yu, V. A. Parisi, A. R. Egan, and M. Morrison. 2005. Novel microbial diversity adherent to plant biomass in the herbivore gastrointestinal tract, as revealed by ribosomal intergenic spacer analysis and rrs gene sequencing. Environ. Microbiol. 7:530-543.

Leng, R. A., M. Gill, T. J. Kempton, J. B. Rowe, J. V. Nolan, S. J. Stachiw, and T. R. Preston. 1981. Kinetics of large ciliate protozoa in the rumen of cattle given sugar cane diets. Br. J. Nutr. 46:371-384.

Leng, R. A., and J. V. Nolan. 1984. Nitrogen metabolism in the rumen. J. Dairy Sci. 67:1072-1089.

Lewis, W. D., J. A. Bertrand, and T. C. Jenkins. 1999. Interaction of tallow and hay particle size on ruminal parameters. J. Dairy Sci. 82:1532-1537.

Loor, J. J., K. Ueda, A. Ferlay, Y. Chilliard, and M. Doreau. 2004. Biohydrogenation, duodenal flow, and intestinal digestibility of trans fatty acids and conjugated linoleic acids in response to dietary forage:concentrate ratio and linseed oil in dairy cows. J. Dairy Sci. 87:2472-2485.

Marounek, M., K. Fliegrova, and S. Bartos. 1989. Metabolism and some characteristics of ruminal strains of Megasphaera elsdenii. Appl. Environ. Microbiol. 55:1570-1573.

Matz, C., and S. Kjelleberg. 2005. Off the hook - How bacteria survive protozoan grazing. Trends Microbiol. 13:302-307.

Nagaraja, T. G., C. J. Newbold, C. J. Van Nevel, and D. I. Demeyer. 1997. Manipulation of rumen fermentation. Pages 523-632 in The Rumen Microbial Ecosystem. P. N. Hobson and C. S. Stewart, ed. Chapman and Hall, London, UK.

Newbold, C. J., N. R. McEwan, R. E. Calza, E. N. Chareyron, S. M. Duval, S. C. P. Eschenlauer, F. M. McIntosh, N. Nelson, A. J. Travis, and R. J. Wallace. 2005. An NAD+-dependent glutamate dehydrogenase cloned from the ruminal ciliate protozoan, Entodinium caudatum. FEMS Microbiol. Lett. 247:113-121.

Newbold, C. J., F. M. McIntosh, P. Williams, R. Losa, and R. J. Wallace. 2004. Effects of a specific blend of essential oil compounds on rumen fermentation. Anim. Feed Sci. Technol. 114:105-112.

Notley, L., and T. Ferenci. 1996. Induction of RpoS-dependent functions in glucose-limited continuous culture: What level of nutrient limitation induces the stationary phase of Escherichia coli? J. Bacteriol. 178:1465-1468.

NRC (National Research Council). 2001. Nutrient Requirements of Dairy Cattle. 7th rev. ed. Natl. Acad. Sci., Washington, DC.

Oba, M., and M. S. Allen. 2003. Effects of diet fermentability on efficiency of microbial nitrogen production in lactating dairy cows. J. Dairy Sci. 86:195-207.

Offner, A., and D. Sauvant. 2004. Comparative evaluation of the Molly, CNCPS, and LES rumen models. Anim. Feed Sci. Technol. 112:107-130.
Oldick, B. S., and J. L. Firkins. 2000. Effects of degree of fat saturation on fiber digestion and microbial protein synthesis when diets are fed twelve times daily. J. Anim. Sci. 78:2412-2420.

Oldick, B. S., J. L. Firkins, and R. A. Kohn. 2000. Compartmental modeling with nitrogen-15 to determine effects of degree of fat saturation on intra-ruminal $\mathrm{N}$ recycling. J. Anim. Sci. 78:2421-2430.

Ozutsumi, Y., K. Tajima, A. Takenaka, and H. Itabashi. 2005. The effect of protozoa on the composition of rumen bacteria in cattle using 16S rRNA gene clone libraries. Biosci. Biotechnol. Biochem. 69:499-506.

Ozutsumi, Y., K. Tajima, A. Takenaka, and H. Itabashi. 2006. Realtime PCR detection of the effects of protozoa on rumen bacteria in cattle. Curr. Microbiol. 52:158-162.

Punia, B. S., J. Leibholz, and G. J. Faichney. 1992. Rate of production of protozoa in the rumen and the flow of protozoal nitrogen to the duodenum in sheep and cattle given a pelleted diet of lucerne hay and barley. J. Agric. Sci. 118:229-236.

Qiu, X., M. L. Eastridge, K. E. Griswold, and J. L. Firkins. 2004. Effects of substrate, passage rate, and $\mathrm{pH}$ in continuous culture on flows of conjugated linoleic acid and trans C18:1. J. Dairy Sci. 87:3473-3479.

Regensbogenova, M., P. Pristas, P. Javorsky, S. Y. Moon-van der Staay, G. W. M. van der Staay, J. H. P. Hackstein, C. J. Newbold, and N. R. McEwan. 2004. Assessment of ciliates in the sheep rumen by DGGE. Lett. Appl. Microbiol. 39:144-147.

Ricard, G., N. R. McEwan, B. E. Dutilh, J.-P. Jouany, D. Macheboeuf, M. Mitsumori, F. M. McIntosh, T. Michalowski, T. Nagamine, N. Nelson, C. J. Newbold, E. Nsabimana, A. Takenaka, N. A. Thomas, K. Ushida, J. H. P. Hackstein, and M. A. Huynen. 2006. Horizontal gene transfer from bacteria to ciliates indicates adaptation to their anaerobic, carbohydrates-rich environment. BMC Genomics 7:22.

Russell, J. B. 1998. Strategies that ruminal bacteria use to handle excess carbohydrate. J. Anim. Sci. 76:1955-1963.

Russell, J. B., and A. J. Houlihan. 2003. Ionophore resistance of ruminal bacteria and its potential impact on human health. FEMS Microbiol. Rev. 27:65-74.

Russell, J. B., J. D. O'Connor, D. G. Fox, P. J. Van Soest, and C. J. Sniffen. 1992. A net carbohydrate and protein system for evaluating cattle diets: I. Ruminal fermentation. J. Anim. Sci. 70:3551-3561.

Sauer, F. D., V. Fellner, R. Kinsman, J. K. G. Kramer, H. A. Jackson, A. J. Lee, and S. Chen. 1998. Methane output and lactation response in Holstein cattle with monensin or unsaturated fat added to the diet. J. Anim. Sci. 76:906-914.

Schloss, P. D., and J. Handelsman. 2003. Biotechnical prospects from metagenomics. Curr. Opin. Biotechnol. 14:303-310.

Schujman, G. E., and D. de Mendoza. 2005. Transcriptional control of membrane lipid synthesis in bacteria. Curr. Opin. Microbiol. 8:149-153

Seo, S., L. O. Tedeschi, C. G. Schwab, B. D. Garthwaite, and D. G. Fox. 2006. Evaluation of the passage rate equations in the 2001 dairy NRC model. J. Dairy Sci. 89:2327-2342.

Skillman, L. C., A. F. Toovey, A. J. Williams, and A.-D. G. Wright. 2006. Development and validation of a real-time PCR method to quantify rumen protozoa and examination of variability between Entodinium populations in sheep offered a hay-based diet. Appl. Environ. Microbiol. 72:200-206.

Stern, M. D., G. A. Varga, J. H. Clark, J. L. Firkins, J. T. Huber, and D. L. Palmquist. 1994. Evaluation of chemical and physical properties of feeds that affect protein metabolism in the rumen. J. Dairy Sci. 77:2762-2786.

Sylvester, J. T. 2005. Development and evaluation of new techniques to quantify ruminal pool size and duodenal flow of protozoal nitrogen. PhD Diss. The Ohio State University, Columbus.

Sylvester, J. T., S. K. R. Karnati, Z. Yu, M. Morrison, and J. L. Firkins. 2004. Development of an assay to quantify rumen ciliate protozoal biomass in cows using real-time PCR. J. Nutr. 134:3378-3384.

Sylvester, J. T., S. K. R. Karnati, Z. Yu, C. J. Newbold, and J. L. Firkins. 2005. Evaluation of a real-time PCR assay for measur- 
ing the ruminal pool and duodenal flow of protozoal nitrogen. J. Dairy Sci. 88:2083-2095.

Ueda, K., A. Ferlay, J. Chabrot, J. J. Loor, Y. Chilliard, and M. Doreau. 2003. Effect of linseed oil supplementation on ruminal digestion in dairy cows fed diets with different forage:concentrate. J. Dairy Sci. 86:3999-4007.

Vlaemink, B., V. Fievez, D. Demeyer, and R. J. Dewhurst. 2006. Effect of forage:concentrate ratio on fatty acid composition of rumen bacteria isolated from ruminal and duodenal digesta. J. Dairy Sci. 89:2668-2678.

Voelker, J. A., and M. S. Allen. 2003. Pelleted beet pulp substituted for high-moisture corn: 3. Effects on ruminal fermentation, $\mathrm{pH}$, and microbial protein efficiency in lactating dairy cows. J. Dairy Sci. 86:3562-3570.

Walker, N. D., C. J. Newbold, and R. J. Wallace. 2005. Nitrogen metabolism in the rumen. Pages 71-115 in Nitrogen and Phos- phorus Nutrition of Cattle. E. Pfeffer and A. Hristov, ed. CABI Publishing, Cambridge, MA.

Wallace, R. J., and C. A. McPherson. 1987. Factors affecting the rate of breakdown of bacterial protein in rumen fluid. Br. J. Nutr. 58:313-323.

Warner, A. C. I. 1962. Some factors influencing rumen microbial populations. J. Gen. Microbiol. 28:129-146.

Williams, A. G., and G. S. Coleman. 1992. The Rumen Protozoa. Springer-Verlag, New York, NY.

Yang, C.-M. J., and G. A. Varga. 1993. The effects of continuous ruminal dosing with dioctyl sodium sulphosuccinate on ruminal and metabolic charateristics of Holstein cows. Br. J. Nutr. 69:397-408.

Yu, Z., M. Yu, and M. Morrison. 2006. Improved serial analysis of V1 ribosomal sequence tags (SARST-V1) provides a rapid, comprehensive, sequence-based characterization of bacterial diversity and community composition. Appl. Environ. Microbiol. 8:603-611. 